\title{
EGY SERTÉSHÚS FELDOLGOZÓ ÜZEM VÁLLALATI TEVÉKENYSÉGÉNEK BEMUTATÁSA, VALAMINT AZ ÚJ FÜSTÖLÉSTECHNOLÓGIAI BERUHÁZÁSÁVAL KAPCSOLATOS VÁLLALAT GAZDASÁGTANI ÉS PÉNZÜGYI SZÁMÍTÁSAI
}

\section{Zsótér Brigitta - Túri István}

\begin{abstract}
Absztrakt: A sertéstenyésztés, illetve a sertéshústermelés és feldolgozás, valamint ezek logisztikája egyre nehezebb helyzetben van napjainkban. Ezt figyelembe véve egyre nehezebb egy vállalatnak egy sertéshús feldolgozó üzemet beindítania és müködtetnie, úgy, hogy az gazdaságos is legyen. Egy ilyenfajta üzem logisztikai folyamatainak fontos része a füstölö rendszer, mely a feldolgozott hústermékeknek nem csupán ízét, hanem illatát, illetve tartósságát is meghatározza. Egy füstölö rendszer gazdaságossági számításait végeztük el a megtérülési idő, a diszkontált megtérülési idő, a nettó jelenérték, a belsö kamatláb és a jövedelmezőségi index kiszámításával. Ezeket a 20, a 40, a 60 , a 80 és a 100 százalékos kibocsátási szintnél vizsgáltuk meg. Ezen számítások elvégzése után megállapítható, hogy a 60 százalékos szinttől kezdődően jövedelmezỏ a beruházás.
\end{abstract}

\begin{abstract}
Nowadays, pig farming, pork production and processing together with their logistics is in a more and more problematic situation. Considering it, it is getting more and more demanding for an entrepreneur to start and run a pork processing plant in a way to stay economical. The smoking system is a very important part of a plant like this, which has effect not only on the taste and smell of the processed meat but also on its lasting, too. We completed the economical calculations of a smoking system like this, calculating the payback time, the discounted payback time, the net present value, the internal interest rate and the profitability index. We examined them at the output levels of 20,40,60, 80 and $100 \%$. After the completion of these calculations, it can be concluded that the investment can be considered as profitable from the level of $60 \%$.
\end{abstract}

Kulcsszavak: beruházás, feldolgozó üzem, vállalati tevékenység, gazdaságossági számítás, megtérülés, jövedelmezöség

Keywords: investment, processing plant, corporate activity, economical calculation, return, profitability

\section{Bevezetés}

A vizsgált egyéni vállalkozó jelenleg szántóföldi növénytermesztéssel és állattenyésztéssel foglalkozik. Méretét tekintve a mikrovállalkozásokhoz sorolható, hiszen három embert foglalkoztat. Kettő dolgozik a növénytermesztésben, egy pedig az állatokért felel. A növénytermesztésbe beletartozik a búza, repce, kukorica, napraforgó, árpa, zab termesztése, míg az állattenyészés a juh, szarvasmarha, sertés és pulyka tenyésztését foglalja magába. A tevékenységei során nagyon fontos a pontos ellátás, a határidők betartása, hiszen a legmagasabb hozam elérésére mindkettő számára a fejlődési szakaszhoz legmegfelelőbb tápanyagellátást kell biztosítani. Ezért fontos a tápszerek, növényvédőszerek, tápok megfelelö rendszerben történő beszerzése. Ezek mellett fontos megemlíteni azt is, hogy az eladásra szánt jószágok, termények eladása is pontos logisztikát igényel, hiszen, ha azok nem a megfelelő időben vannak eladva, elszállítva a vállalkozó komoly bevételtől eshet el. 
A vállalkozó 2019-ben kezdi meg új tevékenységét egy élelmiszeripari pályázat elnyerésének segítségével. A pályázat keretén belül lehetősége van egy új vágóhíd és húsfeldolgozó kialakítására. A vágóhíd alkalmas egy sertés felbontására, valamint hasított félsertés előállítására. A húsfeldolgozóban a sertés minden részét fel kívánja használni a vállalkozó. Tökehúsok árusítása mellett fontosnak tartja, hogy késztermékeket is áruban bocsásson. Ilyen késztermékek például a kolbász, sonka vagy akár a májas.

A füstölt termékek előállításához szükség van egy füstölőberendezésre, amely beszerzésére a pályázaton belül lehetőség van. A pályázat megvalósulását négy mérföldkőben határozták meg és ezeken belül a harmadikban kerül a füstölőrendszer beszerzésre. A vizsgált rendszer hat nagyobb részből áll. Ezek a gyorsérlelö-füstölő klíma, az utóérlelő klíma, a füstgenerátor, egy hưtő-fütő egység a gyorsérlelö-füstölő klímához, egy hütő-fütő egység az utóérlelő klímához, valamint három darab klíma ajtó. A rendszer $14-24^{\circ} \mathrm{C}$ közötti hőmérsékleten füstöl. Egy vállalkozás célja a minél magasabb profit, így szükség van bizonyos számítások elvégzéséhez, hogy lássuk, hogy a berendezés mekkora jövedelmet képes termelni, illetve milyen hosszú idő alatt térül meg a beruházása a vállalkozónak.

\section{Anyag és módszer}

\subsection{Füstölés, füstölési módszerek}

A füstölés az egyik legrégebbi tartósítási módszer a különbözö húskészítmények számára. Alkalmazása sok szempont miatt lényeges. Növeli az eltarthatóságot, a minőséget mindezek mellett pedig az ízre, porhanyớsságra, színre is pozitív hatással van (Kanyó, Kasza 2007).

Ha a füst höfoka $+20^{\circ} \mathrm{C}$ alatt van akkor hidegfüstölésröl beszélhetünk. Ilyen füstölési módszerrel kezelik a szalonnákat, szárazáruféléket, a hagyományos, módszerrel pácolt húsárukat, illetve a száraz és nyers kolbászokat. A hidegfüstölést idötartam szerint kétféleképpen tudjuk megkülönböztetni. Az egyik a rövid hidegfüstölés amikor sürü hidegfüstben kezelik a terméket csupán pár napig. A másik a hosszú hidegfüstölés során pedig akár hetekig, hónapokig is füstölés alatt lehet a készítmény (Juhász, 2000).

\subsection{Gazdaságossági számítások}

Az új füstöléstechnológiával kapcsolatos számítások során öt gazdaságossági számítást alkalmaztunk. Az első a megtérülési idő, mely megadja, hogy a kezdő pénzáramlástól mennyi idő telik el, míg a beáramló pénzáramok kiegyenlítik azt (Bélyácz, 2007). A második a diszkontált megtérülési idő, mely megmutatja, hogy a beruházás hány év diszkontált jövedelméből térül meg (Illés, 2007). A harmadik a nettó jelenérték, amely segítségével választ kapunk arra, hogy a beruházás meghatározott időszakában mennyi lesz diszkontált pénzáramok összessége (Cinnamon-Helweg-Larsen, 2005). A negyedik a belső megtérülési ráta, mely egy belső kamatláb, amely megmutatja egységnyi befektetés várható hozamát (PálinkóSzabó, 2008). Végül pedig a jövedelmezöségi indexet számítottuk ki, mely az 
egységnyi befektetés utáni várható nyereséget mutatja meg (Bélyácz, 2007). Mindezek fontos részei a tervezésnek és a megvalósításnak, így a controlling munka is komoly szerepet kap a beruházás során. (Gal et al., 2008).

\section{Eredmények és értékelésük}

A vizsgált füstölörendszer hidegfüstölésre képes a maga $14-24{ }^{\circ} \mathrm{C}$-os hỏmérséklettartományával. Ezáltal megállapíthatjuk, hogy a vizsgált füstölöberendezés a pácolt húsok, különbözỏ kolbászok, szalonna előállítására alkalmas. A gyorsérlelö-füstölő klímában a termékek 3-10 napos füstölési időtartamig vannak, tehát rövid hidegfüstölés során érik el a megfelelő minőséget a füstgenerátor által termelt sürü, hidegfüstben. A füstgenerátor száraz, kemény fával termeli a klíma számára a füstöt.

A füstölt termékek elkészítése több fázison keresztül valósul meg. Elöször legyártják az húsalapanyagokat. Ezután a füstöléshez megfelelő állagúvá, ízüvé, méretűvé kell tenni az alapanyagokat. Ezalatt kapnak a termékek füszereket, adalékokat vagy ilyenkor történik a töltés is. Ezek után következhet a füstölés, amely során a terméket elöször a gyorsérlelö-füstölö klímába tolják kocsikon. Itt pár napig füstölik, mely segítségével jobb ízt, illatot, minőséget kap és hosszabb ideig lesz eltartható. Végezetül a gyorsfüstölő után az utóérlelő klímába tolják át a terméket, ahol már konkrét füstölés nem lép fel csupán további érlelés. Az itt elkészült terméket innen viszik át a készáru raktárba, ahonnan elszállításra kerülnek a különböző eladókhoz.

A gazdaságossági számítások elvégzéséhez először ki kellett számolnom, hogy a különböző szintekhez milyen pénzáramlások tartoznak. Elöször is a kezdö pénzáramlást számoltam ki, amely minden esetben ugyanannyi, hiszen a berendezés megvásárlásának értéke nem változik. Ez, az 50 százalékos támogatottságot is figyelembe véve, 17406620 Ft. Ezután következett az éves nettó müködési pénzáramlás megállapítása, amely az árbevétel, a költségek, az amortizáció és a társasági adó figyelembe vételével történik. A 20 százalékos szintnél 2776667,69 Ft, a 40 százalékosnál $2862179,31 \mathrm{Ft}$, a 60 százalékosnál $3934045,67 \mathrm{Ft}$, a 80 százalékosnál 4482 841,16 Ft, míg a 100 százalékos kibocsátásnál 5293 172,08 Ft éves müködési pénzáramlással lehet számolni.

Ezt követte a megtérülési idő kiszámítása, mely egy beruházás megtérülésének idejét mutatja.

$$
\mathrm{PB}=\frac{\text { Kezdő befektetés összege }}{\text { Várható évi nettó pénzáram }}=\frac{17406620 \mathrm{Ft}}{2776667,69 \mathrm{Ft}}=6,27 \text { év }
$$

20-nál 6,27 év, 40-nél 6,08 év, 60-nál 4,42 év, 80-nál 3,88 év és 100-nál 3,29 év jött ki.

A diszkontált megtérülési idő egy speciális esete a megtérülési időnek, mely már a pénz időértékét is figyelembe veszi. 


$$
\begin{aligned}
& \text { Diszkontált megtérülési idő }=\frac{\text { Kezdő tőkebefektetés }}{\text { Éves nettó pénzáram }}= \\
& =\frac{17406620 \mathrm{Ft}}{2776667,69 \mathrm{Ft}}=6,27
\end{aligned}
$$

A diszkontált megtérülési idő 20 - és $40 \%$-nál 9 év, 60\%-nál 6 év, 80\%-nál 5 év és $100 \%$-nál 4 év.

A harmadik vizsgált gazdaságossági módszer a nettó jelenérték, amelyet a legföbb döntési kritériumnak szoktak meghatározni, hiszen ez mutatja meg valojában, hogy mekkora jövedelemre tehet szert a beruházás alatt a vállalkozó.

$$
\begin{gathered}
\mathrm{NPV}=-\mathrm{C}_{0}+\sum_{\mathrm{t}=1}^{\mathrm{n}} \frac{\mathrm{C}_{\mathrm{t}}}{(1+\mathrm{r})^{\mathrm{t}}}=-\mathrm{C}_{0}+\mathrm{PV}= \\
=-17406620 \mathrm{Ft}+ \\
+\left(\frac{2776667,69}{(1+0,08) 1}+\frac{2776667,69}{(1+08) 2}+\frac{2776667,69}{(1+0,08) 3}+\frac{2776667,69}{(1+0,08) 4}\right. \\
\left.+\frac{2776667,69}{(1+0,08) 5}+\frac{2776667,69}{(1+0,08) 6}+\frac{2776667,69}{(1+0,08) 7}\right)= \\
=-2950260,50 \mathrm{Ft}
\end{gathered}
$$

A $20 \%$-os szintnél - $2950260,50 \mathrm{Ft}$, a $40 \%$-os szintnél - $2505055,34 \mathrm{Ft}$, a $60 \%$-os szintnél $3075477,58 \mathrm{Ft}$, a $80 \%$-os szintél $5932709,99 \mathrm{Ft}$ és a 100\%-os szintnél $10151592,65 \mathrm{Ft}$ a nettó jelenérték.

A belső kamatlábat az elvárt hozammal összehasonlítva alkalmazzák és a beruházásból származó pénzáramok együttes jelenértéke nullával egyenlö. A hasonló kockázatú projektektỏl elvárt hozam $8 \%$.

$$
\begin{gathered}
-\mathrm{C}_{0}+\sum_{\mathrm{t}=1}^{\mathrm{n}} \frac{\mathrm{C}_{\mathrm{t}}}{(1+\mathrm{IRR})^{\mathrm{t}}}=0 \\
\text { IRR }=\frac{\text { Kezdő tőkebefektetés }}{\text { Éves nettó pénzáram }}=\frac{17406620 \mathrm{Ft}}{2776667,69 \mathrm{Ft}}=6,27 \\
\text { PVIFA (r\%, 7év) }=3 \%
\end{gathered}
$$

A 20\%-hoz tartozó belső kamatláb 3\%, a 40-hez tartozó 4\%, a 60-hoz tartozó $11 \%$, a 80 -hoz tartozó $17 \%$, a $100 \%$-hoz tartozó pedig $24 \%$. 
Végül a megtérülési ráta kiszámítása következett, amely ezt mutatja meg, hogy 1 Ft befektetés hány forint bevételt hoz.

$$
\mathrm{Pl}=\frac{\sum_{\mathrm{t}=1}^{\mathrm{n}} \frac{\mathrm{C}_{\mathrm{t}}}{(1+\mathrm{r})^{\mathrm{t}}}}{\mathrm{C}_{0}}=\frac{14456359,50 \mathrm{Ft}}{17406620 \mathrm{Ft}}=0,83
$$

A $20 \%$-hoz 0,83 -as, a $40 \%$-hoz 0,86 -os, a $60 \%$-hoz 1,18 -as, a $80 \%$-hoz 1,34 -es és a $100 \%$-hoz 1,58-as jövedelmezőség indexszel számolhat a vállalkozó.

\section{Következtetések, összegzés, záró megjegyzések, záró gondolatok}

A vállalkozó számára a különböző pácolt húsok, kolbászok, szalonna készítése lényeges, hiszen így elég széles termékskálát tud nyújtani a vevők számára, melyek elkészítéshez a füstölörendszer tökéletesen alkalmas. A feldolgozó mellett a vágóhíd is rendkívül fontos, hiszen így nem kell a különböző késztermékek minden alapanyagát megvásárolni, hanem a vállalkozó saját maga számára képes azokat előállítani. A termékek árának kialakításánál először valamivel alacsonyabb, bevezető árakat alkalmaz, hogy bevezesse a piacra a terméket. Fontos megjegyezni azt is, hogy nemcsak késztermékek, hanem tőkehúsok árusításával is foglalkozni kíván, így éttermek, élelmiszerboltok kiszolgálása mellett akár saját hentesbolt kialakítására vagy egy ugyanilyen másik bolt kiszolgálására is van lehetősége. Mivel ez egy kisebb létesítmény, így akár egy szervezet részeként több, ugyanekkora üzemmel már országos szinten is jelentősek lehetnek. A reklámozás terén saját internetes oldal, illetve újságoknál való hirdetés útján próbál minél nagyobb ismeretségre szert tenni a termékekkel.

A vállalkozó számára idegen forrásként hitelt kell felvennie a teljes beruházás megvalósításához. A tervezett vágóhíd és húsfeldolgozó 5 húsipari szakembert igényel, akik számára átlagnál magasabb fizetést szükséges adni.

A magas fizetési igény, a piacra lépés újdonsága miatt a vállalkozás számára a költségek megfelelő szinten tartása lényeges szempont. Ennek megvalósulása érdekében a logisztikai folyamatok nagy hangsúlyt kapnak. A pontos beszerzés, árukiszállítás lényeges lesz, hiszen egy jól, olajozottan müködő rendszer a költségek csökkentését, ezáltal a nyereség nagyobbá tételét eredményezheti.

Az 5 kibocsátási szint összehasonlítása során az összes gazdaságossági módszer esetében a 100 százalékos kihasználtság bizonyult a legjövedelmezőbbnek illetve, hogy a beruházás már 60 százalékos szint esetében is jövedelmező. Ennek ellenére figyelembe kell venni, hogy egy vállalkozó számára nagyon fontos a fizetőképességének megörzése, így lehet, hogy a nagyobb jövedelmet feláldozza, hogy a kisebb müködési költséggel tudjon számolni a későbbiekben. Ezen szempontot figyelembe véve a 60 és a 80 százalékos kihasználtságot javasolnám, hiszen ezek még a 20 és a 40 százalékossal ellentétben nyereségesek és mégsem jelentenek akkora költségterhet, mintha teljes kapacitással müködne a berendezés. 


\section{Köszönetnyilvánítás}

Támogatónk az Emberi Eröforrások Minisztériuma, az Emberi Erőforrás Támogatáskezelő és a Nemzeti Tehetség Program (NTP-HHTDK-017-0004).

WNBERI EROOFORRAS

TÁMOGATASKEZLLOO

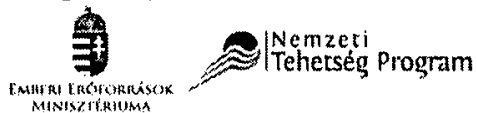

\section{Irodalomjegyzék}

Bélyácz I. (2007): A vállalati pénzügyek alapjai. Aula Kiadó, Budapest.

Cinnamon, R., Helweg-Larsen, B. (2002): How come you don't understand your account? - The essential guide to financial management, In.: Szász G. (2005): A vállalkozás pénzügyi folyamatainak megértése: nélkülözhetetlen útmutató a pénzügyi menedzsmenthez. Alexandra Kiadó, Pécs.

Gál J., Kmosko É. (2008): Connecting Points of Logistics, Product Management and Controlling at Manufacturing Companies (A logisztika, a termelésmenedzsment és a controlling kapcsolata a termelővállalatoknál). Review of Faculty of Engineering (Analecta Technica Szegedinensia), 2 (1): 31-37.

Illés Ivánné (2007): Vallalkozások pénzügyi alapjai. SALDO Pénzügyi Tanácsadó és Informatikai Zrt., Budapest.

Juhász Károlyné (2000): Hüsipari technológia II. Agrároktatási Intézet, Budapest.

Kanyó T., Kasza J. (2007): Tartósítóipari technológia I. FVM Vidékfejlesztési, Képzési és Szaktanácsadási Intézet, Budapest.

Pálinkó É., Szabó M. (2008): Vállalati pénzügyek. Typotex, Budapest. 